\title{
Opieka duchowa w więzieniach Królestwa Polskiego w latach 1815-1867 na przykładzie więzienia piotrkowskiego
}

\section{Wstęp}

Tak pokazują dzieje więziennictwa istnienie opieki duchowej w zakładach karnych bezpośrednio związane było z poglądami na cele, jakie miała spełniać kara pozbawienia wolności. Kapelani więzienni zasadniczo nie byli potrzebni do czasu, gdy nie zakładano możliwości poprawy moralnej przestępcy, a podstawową przesłanką polityki karnej była zasada odstraszania, a nie resocjalizacji ${ }^{1}$.

Pierwsze zalążki koncepcji poprawczej (choć bardzo jeszcze nieśmiałe) pojawiły się w Polsce w połowie XVI w. w instrukcji kanclerza Osieckiego wydanej staroście rawskiemu $\mathrm{w}$ sprawie traktowania więźniów (około $1550 \mathrm{r}$.) ${ }^{2}$.

Jednakże dopiero przełom XVIII i XIX w. przyniósł zasadnicze zmiany. Było to związane $\mathrm{z}$ wykształceniem się idei humanitaryzacji zasad wykonywania kary pozbawienia wolności, w tym potrzeby wychowawczego oddziaływania na sprawcę ${ }^{3}$. Już nie chodziło tylko o zadanie pokuty (o odwet wobec sprawcy), ale także o to, aby przestępca wychodzący na wolność nie stanowił zagrożenia dla bezpieczeństwa społecznego. Zaczęto dostrzegać, że uwięzienie daje możliwości wpływania na osobę skazanego tak, aby nastąpiła jego wewnętrzna przemiana ${ }^{4}$.

I tak Ksawery Potocki już w 1818 r. w swoim Projekcie ogólnego i szczególnego polepszenia stanu $i$ administracji więzień wylicza elementy służące poprawie moralnej, takie jak: wprowadzenie klasyfikacji przestępców, zapewnienie im pracy, zatrudnienie odpowiedniego personelu więzien-

${ }^{1}$ J. Nikołajew, Duszpasterstwo więzienne. Tradycje. Teraźniejszość. Perspektywy, Lublin 2009, s. 13.

${ }^{2}$ T. Czacki, O litewskich i polskich prawach, t. II, Warszawa 1801, s. 100.

${ }^{3}$ E. S. Rappaport, Polityka kryminalna w zarysie, Łódź 1948, s. 67-68.

${ }^{4}$ J. Śliwowski, Narodziny prawa penitencjarnego, Warszawa 1934, s. 3-4. 
nego, sprawiedliwe i ludzkie obchodzenie się z osadzonymi, narzucenie im reguł skromnego zachowania się i obowiązku przestrzegania higieny, a także „ćwiczenia religijne i nauki moralne. Religia, mówi Bentham, działa tam, gdzie oczy i ręce rządu ludzkiego dosięgnąć nie są w stanie, to iest prowadzi i krępuje wolę i przekonanie wewnętrzne człowieka w czynnościach przed bacznością ludzką ukrytych, lub łatwo ukryć się mogących. Zastępuie więc niedokładność postanowień i postrzeżeń ludzkich"5.

Również inni polscy reformatorzy penitencjarni, jak np. Julian Ursyn Niemcewicz ${ }^{6}$, Fryderyk Skarbek ${ }^{7}$, Józef Pawlikowski ${ }^{8}$, Aleksander Kożuchowski ${ }^{9}$ dostrzegali istotne znaczenie wychowania religijnego $\mathrm{w}$ procesie resocjalizacji.

Wszyscy oni uważali, iż dla osiagnnięcia zamierzonego celu duchowni powinni nie tylko odprawiać okolicznościowe nabożeństwa, ale przede wszystkim nauczać religii, organizować pogadanki z osadzonymi, odwiedzać ich w celach. Być niejako przewodnikami dla skazanych na drodze ich moralnego odrodzenia ${ }^{10}$.

Wysuwane koncepcje penitencjarne determinowały decyzje podejmowane przez centralne organy administracji rządowej Królestwa Polskiego w zakresie organizacji więziennictwa.

W niniejszej publikacji dokonać chcemy analizy stanowionych przez komisje rządowe regulacji prawnych dotyczących zasad i zakresu posługi religijnej w zakładach karnych Królestwa Polskiego, w konfrontacji z praktyką.

Za materiał badawczy z jednej strony posłużą nam przepisy administracyjne zgromadzone w Zbiorze Przepisów Administracyjnych Królestwa Polskiego, a z drugiej znajdujące się w Archiwum Państwowym w Łodzi akta w przedmiocie obrzędów religijnych, zachowane w zespole Więzienie Piotrkowskie ${ }^{11}$. Przy czym zaznaczmy, że są to jedyne akta dotyczące omawianego zagadnienia, na jakie trafiłam badając dzieje więziennictwa w Królestwie Polskim w latach 1815-1867.

W tym miejscu należy jeszcze poczynić uwagę na temat różnego statusu poszczególnych wyznań w Królestwie Polskim, co miało bezpośrednie przełożenie zarówno na regulacje prawne dotyczące zasad udzielania opieki reli-

${ }^{5}$ K. Potocki, Uwagi do projektu ogólnego i szczególnego ulepszenia administracji i stanu więzień publicznych w Królestwie Polskim, Warszawa 1819, s. 20.

${ }^{6}$ J. U. Niemcewicz, O więzieniach publicznych, czyli Domach Pokuty rzecz krótka, Warszawa 1818, s. 48.

${ }^{7}$ F. Skarbek, O poprawie moralney winowayców w więzieniach, Warszawa 1822, s. 12.

${ }^{8}$ J. Pawlikowski, O prawach kryminalnych, Warszawa 1918, s. 74-76.

${ }^{9}$ M. Czerwiec, Więzienioznawstwo. Zarys rozwoju więziennictwa, Warszawa 1958, s. 60.

${ }^{10} \mathrm{~A}$. Osoba, Z dziejów polskiej dziewiętnastowiecznej myśli penitencjarnej, „Przegląd Więziennictwa Polskiego" 2001, nr 32-33, s. 102-124.

${ }^{11}$ Archiwum Państwowe w Łodzi, zespół nr 73, Więzienie Piotrkowskie 1809-1914. 
gijnej, jak i na praktyczne funkcjonowanie duchownych różnych obrządków w więzieniach. I tak ustawa Konstytucyjna z 1815 r. w art. 11 usankcjonowała zasadę uprzywilejowania religii rzymskokatolickiej jako „przedmiotu szczególniejszej opieki rządu", gwarantując jednocześnie wolność pozostałym wyznaniom. Przy czym tylko przynależność do jednego z wyznań chrześcijańskich dawała możliwość używania praw cywilnych i politycznych, co oznaczało pozbawienie tej możliwości wyznawców religii mojżeszowej ${ }^{12}$. Dlatego też oddzielnie omówiona została sytuacja więźniów rzymskokatolickich, Żydów oraz osób innych wyznań chrześcijańskich.

\section{Wyznanie rzymskokatolickie}

Pierwsze przepisy (mające charakter generalny, $\mathrm{tj}$. formalnie odnoszące się do wszelkich obrządków religijnych) dotyczące opieki duchowej w więzieniach pojawiają się już w instrukcji więziennej z 1823 r. Artykuł 21 stanowił, że „więzienia powinny mieć także duchownego dla sprawowania obrządków religijnych"13. Jego obowiązki były dość ograniczone: „duchowny przybyć powinien w każdą niedzielę i święta do więzienia dla odprawiania nabożeństwa, odbycia nauki religijnej, tudzież dla wysłuchania spowiedzi, a oprócz tego przyjść na każde wezwanie do chorego, dla odbycia usługi religijnej" (art. 25) ${ }^{14}$. Nadto więźniowie, stosownie do swego wyznania, zobowiązani byli do odmawiania trzy razy dziennie modlitwy (rano, przed obiadem i wieczorem) ${ }^{15}$.

Obowiązek uczestniczenia przez osadzonych w naukach religijnych przypominał także pochodzący najprawdopodobniej z $1825 \mathrm{r}$. dokument zatytułowany Urządzenia drukowane obejmujące powinności więźni. Pismo to zostało wysłane przez Komisję Województwa Mazowieckiego komisarzowi Obwodu Łęczyckiego z poleceniem przekazania nadzorcom zakładów karnych. W art. 5 czytamy: „wszędzie więźnie zachować się powinni z pokorą ich położeniu właściwą i z przystojnością które szczególniey jednakże widocznymi być maią podczas Nabożeństwa i Nauk Religiynych, przypominających im Boga przestępstwami onychże obrażonego"16.

${ }^{12}$ Szerzej w Historia Państwa i Prawa Polski, red. J. Bardach, t. III, Warszawa 1981, s. $411-416$.

${ }^{13}$ Zbiór Przepisów Administracyjnych Królestwa Polskiego, Wydział Spraw Wewnętrznych [dalej: ZPA], cz. VI, O aresztach i więzieniach, t. I, 1868, s. 339.

${ }^{14}$ Tamże, s. 341.

${ }^{15}$ Tamże, s. 352.

${ }^{16}$ AGAD, Komisja Województwa Mazowieckiego, sygn. 10040. Nie wiemy, kto jest autorem tego dokumentu, czy Komisja Województwa Mazowieckiego, czy też może 
Materiał źródłowy zachowany $\mathrm{z}$ lat dwudziestych i trzydziestych XIX w. jest bardzo skąpy. Są to zasadniczo dwa dokumenty, z których wynika, że więzienie piotrkowskie miało kaplicę, jednak msze odbywały się tam tylko z okazji ważniejszych świąt kościelnych. I tak w piśmie Komisji Województwa Kaliskiego z dnia 26 października 1826 r., kierowanym do nadzorcy więzienia Piotrkowskiego, czytamy: „iż w celu zapewnienia korzyści jubileuszowych więźniom [...] poleca nadzorcy, ażeby zarządzenia duchownych zasadzaiące się na liście pasterskim przez Biskupa Dyecezyi kujawso-kaliskiej wydaną względem udzielenia nabożeństwa więźniom starali się ściśle uskuteczniać". Ów list pasterski przewidywał jedynie, że z okazji "świąt jubileuszowych" kapłani będą w kaplicach więziennych odprawiać nabożeństwa i odbierać od osadzonych spowiedźn ${ }^{17}$.

Reforma więziennictwa przeprowadzona $\mathrm{w}$ latach trzydziestych XIX w. skłoniła władze Królestwa Polskiego do szerszego uwzględnienia roli duchownych $\mathrm{w}$ życiu więziennym, aniżeli tylko odprawianie okolicznościowych mszy. I tak rozporządzenie Komisji Rządowej Spraw Wewnętrznych, Duchownych i Oświecenia Publicznego z 22 stycznia/3 lutego 1838 r. skierowane do arcybiskupa, biskupów i administratorów wszystkich diecezji w Królestwie Polskim stanowiło: „doprowadzając do skutku zamierzoną reorganizację więzień krajowych pragnie komisja rządowa urządzić w nich służbę Bożą w taki sposób, aby duchowny do każdego więzienia jako Kapelan miejscowy przywiązany, przykładał się spólnie ze zwierzchnością administracyjną więzienia, do przywiedzenia moralnej poprawy więźniów, bez której zakłady karne prawdziwego celu osiągnąć nie mogą"18. W świetle nowych zapatrywań duchowni w więzieniach nie mieli się ograniczać jedynie do odprawiania mszy, ale stanowić istotny czynnik na drodze resocjalizacji skazanych. Władze kościelne zostały zobligowane do wyznaczenia w swoich diecezjach kapelanów więziennych. Miały to być ",osoby zdatne, pobożne i gorliwe, które by godnie temu trudnemu, a tyle użytecznemu powołaniu odpowiadać mogły [...] za które ich wyższa nad wszelkie doczesne nagrody, zasługa przed Bogiem czeka"19. Jak zauważa M. Senkowska taka obietnica nagrody była niewystarczająca, a rola duchownych w odnowie moralnej skazanych miała wciąż charakter marginalny. Kościół bardzo niechętnie podchodził

np. Komisja Rządowa Spraw Wewnętrznych i Duchowych. Z treści pisma przewodniego załączonego do dokumentu można odnieść jednak wrażenie, iż Komisja Województwa Mazowieckiego jedynie odgrywa rolę pośrednika, a sam dokument pochodzi od władzy wyższej.

${ }^{17}$ APŁ, Więzienie Piotrkowskie..., sygn. 15.

${ }^{18} \mathrm{ZPA}, \mathrm{cz} . \mathrm{VI}, \mathrm{t}$. IV, s. 111.

${ }^{19}$ Tamże, s. 113. 
do nowych prądów humanitarnych głoszonym przez XIX-wiecznych reformatorów penitencjarnych ${ }^{20}$.

Jak wskazuje decyzja Rady Administracyjnej z dn. 9/21 stycznia 1845 r. istniał realny problem $\mathrm{z}$ obsadzaniem funkcji kapelanów więziennych. Było to silnie związane $\mathrm{z}$ ich niskim uposażeniem - zazwyczaj otrzymywali rocznej pensji nie więcej niż 45 rubli. I tak np. Rada Administracyjna wskazuje przypadek kompanii poprawczej w twierdzy w Zamościu, gdzie z powodu braku kapelana więziennego, osadzeni musieli być doprowadzani na msze do kościoła parafialnego, co było po pierwsze sprzeczne z wytycznymi instrukcji więziennej z 1823 r., a po drugie stwarzało niebezpieczeństwo ucieczki skazanych. Takiemu stanowi rzeczy zaradzić miała decyzja zezwalająca na łączne pobieranie pensji z tytułu pełnienia funkcji kapelana więziennego i świadczeń emerytalnych do kwoty 300 rubli rocznie: „gdy zapytana w tym względzie Komisja Rządowa Przychodów i Skarbu oświadczyła: iż skoro Duchowieństwo wyznania Rzymsko-Katolickiego nie należy do stowarzyszenia emerytalnego urzędników, zatem nie ma nic do nadmienienia, ze względu na przepisy emerytalne; z uwagi wszakże na fundusze skarbowe, była zdania, iż podobne łączenie pensy powinniby mieć pewną granicę, to jest tylko wtenczas następować, kiedy jedne i drugie pensye nie przenoszą razem rs 300 rocznie" 21 .

Niski poziom opieki duchowej odnotowano także w więzieniu piotrkowskim. $Z$ analizowanych dokumentów wynika, że nabożeństwa odprawiane były tylko raz w roku z okazji Wielkanocy, wtedy też więźniowie mogli przystąpić do spowiedzi i przyjąć komunię. Ślady jakiejkolwiek innej działalności duchownych rzymskokatolickich w więzieniu piotrkowskim nie zachowały się, choć oczywiście nie możemy wykluczyć, że odbywała się ona. Wydaje się to jednak mało prawdopodobne. W badanym zespole znajduje się pismo Komisji Rządowej Spraw Wewnętrznych i Duchownych z dn. 27 sierpnia/4 września 1847 r. skierowane do biskupa parafii piotrkowskiej w przedmiocie zasad odbywania nabożeństw w więzieniach, w którym komisja przypomina, iż w świetle obowiązujących przepisów więźniowie mają prawo odbywać praktyki religijne i w związku z tym uprasza biskupa, „aby ze swej strony stosowne dyspozycje i rozporządzenia komu należy wydać raczył". Nadto komisja rządowa zwróciła uwagę, że księża powinni uświadamiać więźniom istotną rolę jaką odgrywa religia w procesie ich resocjalizacji: „pominąć nie można, iż należałoby również polecić roztropności do nabożeństw więziennych maiących użyć się duchownych, iżby objaśniali

${ }^{20}$ M. Senkowska, Kara więzienia w Królestwie Polskim w pierwszej połowie XIX wieku, Wrocław-Warszawa-Kraków 1961, s. 142.

${ }^{21} \mathrm{ZPA}, \mathrm{cz} . \mathrm{VI}$, t. IV, s. 119. 
przestępcom $\mathrm{w}$ więzieniach osadzonym, iż akt religijny jubileuszowy złagodzić może ich winy pod względem duchowym, że skoro zaś następnie odpokutują jeszcze karę przez rząd na nich wymierzona, wówczas staną się ludźmi odnowionymi, z wszelkiej skazy oczyszczonymi i do nowego życia usposobionymi"22. Takie polecenie ze strony władz rządowych być może zostało podyktowane faktem, że sami skazańcy nie byli zainteresowani odnową moralną poprzez uczestnictwo w obrządkach religijnych.

By zachęcić aresztantów do gorliwego uczestniczenia w nabożeństwach religijnych Komisja Rządowa Spraw Wewnętrznych i Duchownych reskryptem z dn. 8/20 lipca 1849 r. objawiła ukaz Rządzącego Senatu z 8 marca 1849 r. zwalniający skazanych $\mathrm{z}$ obowiązku pracy $\mathrm{w}$ dzień tygodnia, w którym zgodnie z ich wyznaniem odbywają się nabożeństwa: „pod względem zwolnienia aresztantów od robót $\mathrm{w}$ dniach tygodnia świąt właściwych każdego wyznania wydane zostały w Cesarstwie ukazem Rządzącego Senatu z dn. 8 marca rb przepisy następujące [...] aby aresztanci wszystkich wyznań nie więcej jak jeden dzień $\mathrm{w}$ tygodniu mieli wolnym, a mianowicie $\mathrm{w}$ ten czas, kiedy według obrządku ich odbywa się nabożeństwo"23.

Wydaje się, że mimo starań władz rządowych o zapewnienie jak najlepszej opieki duchowej więźniom rzymskokatolickim, w kolejnych latach niemal brak jest jakiejkolwiek aktywności księży w więzieniu piotrkowskim (w przeciwieństwie do duchownych innych wyznań). Warto przytoczyć tu pismo nadzorcy piotrkowskiego domu badań z lipca 1857 r. adresowane do przełożonego klasztoru Bernardynów, w którym czytamy: „przy tym mam obowiązek najuprzejmiej prosić o stosowanie rozporządzenia, aby nabożeństwa $\mathrm{w}$ kaplicy domu badań regularnie się odbywały, gdyż ludzie znajdujący się w więzieniu przede wszystkim potrzebują troskliwey baczności po względem religijno-moralnym"24.

W roku 1859 Komisja Rządowa Spraw Wewnętrznych Duchownych wydała nową „instrukcję dla więzień i zakładów karnych Królestwa Polskiego". Już w art. 2 przewidywała urządzenie w każdym zakładzie karnym stałej kaplicy, a gdyby warunki lokalowe na to nie pozwalały, choćby ruchomej, tak aby uniknąć konieczności prowadzania więźniów do miejscowych kościołów ${ }^{25}$. Tytuł VII „o posłudze duchowej” w przeciwieństwie do przepisów z 1823 r. regulował oddzielnie status poszczególnych religii. I tak osoby wyznania rzymskokatolickiego miały mieć zapewnioną stałą „posługę duchową", której miały udzielać miejscowe zgromadzenia zakonne, a w razie ich braku proboszcz danej parafii (art. 82). Nowe prawo

\footnotetext{
${ }^{22}$ APŁ, Więzienie Piotrkowskie..., sygn. 15.

${ }^{23}$ Tamże.

${ }^{24}$ Tamże.

${ }^{25}$ ZPA, cz. VI, t. II, s. 119.
} 
nakładało konkretne obowiązki zarówno na duchownych, jak i przestępców. I tak nabożeństwa miały być odprawiane w każdą niedzielę i święta. Nadto w większych więzieniach duchowni zobowiązani zostali „każdodziennie rano i wieczór odmawiać modły $\mathrm{z}$ aresztantami $\mathrm{w}$ więzieniach większą ludność mających, szczególniej karnych, i za każdym razem dowiadywać się, czy który z chorych nie prosi o pomoc duchowną; przybyć na każde wezwanie Nadzorcy do chorego, pomocy duchowej potrzebującego; być obecnym przy wykonywaniu przysięgi na wierność Najjaśniejszemu Panu przez officyalistów więziennych i protokoły tego wykonania podpisywać" 26 . Nadto duchowni musieli co najmniej dwa razy w tygodniu nauczać małoletnich przestępców zasad religii i moralności (art. 85) ${ }^{27}$. W zakresie wynagrodzenia kapelanów więziennych utrzymano zasady wprowadzone na mocy decyzji Rady Administracyjnej z dnia 9/21 stycznia $1845 \mathrm{r}$.

Co istotne, udział przestępców $\mathrm{w}$ praktykach religijnych przestał mieć charakter dobrowolny. Jak stanowił art. 83 instrukcji: „co niedziela i Święto odprawiane będzie nabożeństwo w kaplicy więziennej, na którym wszyscy aresztanci powinni być obecni, pod ścisłym nadzorem służby więziennej i przy względzie na to, aby żadne znoszenie się między niemi, dla biegu sprawy lub bezpieczeństwa i porządku więziennego szkodliwe, miejsca nie miały" ${ }^{\prime 28}$. Dodatkowo każdy osadzony musiał co najmniej raz w roku przystąpić do spowiedzi (art. 84) ${ }^{29}$.

Czy nowa instrukcja zmieniła zaangażowanie księży rzymskokatolickich $\mathrm{w}$ niesienie posługi duchowej w zakładach karnych? Chyba nie. Na dowód tego wskażmy pismo nadzorcy domu badań w Piotrkowie do księdza gwardiana Ojców Bernardynów z 12/27 marca 1861 r., w którym czytamy: „nadzorca z ubolewaniem musi księdza zawiadomić jako przełożonego klasztoru, iż kapelan [...] z jego klasztoru dla dopełnienia duchowych obowiązków w kaplicy tutejszego więzienia przeznaczony nie pełni w ścisłości swych obowiązków albowiem w święta uroczyste nie przychodzi do odprawiania mszy podając za powód wyjazdu swego na odpusta do sąsiednich probostw" ${ }^{\prime \prime}$ W dalszej części nadzorca wywodzi, że osadzeni „potrzebują troskliwszej duchowej pracy niżeli Ci, którzy na wolności pozostają albowiem Ci nie w jednym to w drugim kościele nabożeństwa wysłuchać mogą zaś więźnie jedynie tylko na spełnienie obrzędów religijnych przez kapelana udzielonych oczekiwać muszą ${ }^{\prime 30}$. W odpowiedzi przełożony Klasztoru Ojców Bernardynów zwrócił się do nadzorcy więzienia piotr-

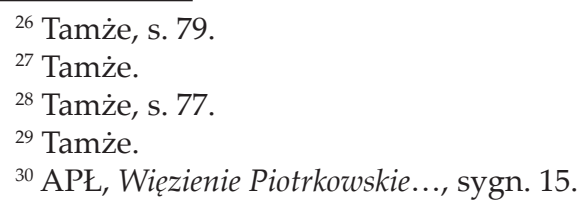


kowskiego o zwolnienie dotychczasowego kapelana z pełnionych funkcji $\mathrm{z}$ uwagi na zbyt niskie wynagrodzenie (45 rubli rocznie). Jednocześnie wyraził chęć pełnienia przez zakonników posługi religijnej w więzieniu piotrkowskim, jeżeli rząd uwzględni ich żądania (nie wiemy, jakich kwot domagało się duchowieństwo). O całej sytuacji nadzorca poinformował naczelnika Powiatu Piotrkowskiego w piśmie z dn. 27 marca/8 kwietnia 1861 r., przekonując o konieczności stałej opieki duchowej nad więźniami: „będąc przekonanym że ludzie w więzieniu osadzeni potrzebują troskliwszej duchowej opieki, regularniejszego dopełniania nauk religii, religijnych obrządków pod każdym względem"31. Jednocześnie zwrócił się do władz powiatowych o wyrażenie przychylnej opinii w przedmiocie żądań finansowych księży rządowi gubernialnemu ${ }^{32}$.

Postulaty kleru nie zostały chyba jednak uwzględnione, w efekcie czego więzienie piotrkowskie straciło stałego kapelana, a jakakolwiek opieka duchowna nad więźniami rzymskokatolickimi w praktyce przestała istnieć. W materiale źródłowym zachował się tylko jeden dokument, z 1862 r., świadczący o planowanej spowiedzi wielkanocnej. W piśmie z dnia 1/13 kwietnia 1865 r. nadzorca ponownie zwrócił się do naczelnika Powiatu Piotrkowskiego o pomoc w tej sprawie: „ponieważ więzienie nie ma kapelana [...] mam honor upraszać Wgo Naczelnika o wyjednanie u konsystorza Foraliego Piotrowskiego delegowanie jednego z księży tak dla udzielania nauki moralnej uwięzionym, jako też odprawiania mszy świętej"33. Niestety apel ten najprawdopodobniej nie przyniósł oczekiwanych skutków. Analizowane akta nie dają podstaw do postawienia tezy, że w latach późniejszych więzienie piotrkowskie miało stałego kapelana. Wręcz przeciwnie, do końca analizowanego okresu w ogóle brak jest śladów, aby w tej jednostce penitencjarnej odbywała się posługa religijna dla więźniów rzymskokatolickich.

Mimo tak małego zaangażowania duchownych zdarzały się przypadki, iż więźniowie innych wyznań wyrażali wolę przejścia na wiarę rzymskokatolicką. I tak np. w czerwcu roku 1863 do nadzorcy więzienia piotrkowskiego zgłosił się starozakonny Abraham Frucht, który oświadczył, że „z własnej pobudki a nie z namowy lub osiągnięcia jakiej korzyści od lat paru, jeszcze przed moim przyaresztowaniem pragnąłem $z$ wewnętrznego przekonania przejść do Kościoła Rzymsko-Katolickiego i przyjąć religię Chrześcijańską"34. W związku z tym nadzorca zwrócił się do konsystorza Foraliego Piotrowskiego o oddelegowanie duchownego, który pomoże osadzonemu przygotować się do przyjęcia chrztu świętego.

\footnotetext{
${ }^{31}$ Tamże.

${ }^{32}$ Tamże.

${ }^{33}$ Tamże.

${ }^{34}$ Tamże.
} 


\section{Wyznanie mojżeszowe}

Początkowo nie było odrębnych przepisów regulujących zasady odbywania praktyk religijnych przez więźniów religii mojżeszowej.

Mimo braku konkretnych uregulowań prawnych w więzieniu piotrkowskim już od lat trzydziestych XIX w. odnotowujemy obecność rabinów, choć była ona jeszcze dosyć sporadyczna. I tak np. zachowało się pismo z 22 kwietnia 1834 r., w którym Sąd Policji Poprawczej Wydziału Piotrkowskiego uwzględniając prośbę Dozoru Bożniczego nakazał dozorcy umożliwić więźniom zgromadzenie się w jednej izbie w celu umożliwienia im odbywania nabożeństw z okazji Świąt Wielkanocnych ${ }^{35}$. Co ciekawe, rabinów wpuszczano nie tylko do więźniów skazanych, ale także będących jeszcze pod śledztwem. I tak np. Sąd Policji Poprawczej Wydziału Piotrkowskiego w piśmie z 21 marca/9 kwietnia 1844 r. zezwolił na wspólne odbycie nabożeństw z okazji Świąt Wielkanocnych aresztantom starozakonnym, wyłączając jedynie 13 osób „przez obawę zmowy z sobą i innymi Żydami"36.

Jak podaje M. Senkowska, „dopiero w latach czterdziestych gminy wyznaniowe rozpoczęły starania o dopuszczenie rabinów do odwiedzania więźniów i udzielania nauk religijnych" ${ }^{\prime 37}$.

Władze rządowe były jednak bardzo niechętne wpuszczeniu rabinów do więzień, uważając że nie dawali „rękojmi, jakie mają za sobą duchowni innych wyznań" ${ }^{38}$. Obawiano się, iżby „pod pozorem pobożności nie ułatwiali więźniom związków z ich wspólnikami na wolności będącymi i gdy obawa takowa, tą mianowicie zdaje się być wsparta okolicznościa, że duchowni starozakonni, tolerując przez tak długi przeciąg czasu dotychczasowy stan rzeczy, dopiero od lat kilku reklamacje swoje w tym względzie podawać zaczęli" ${ }^{39}$.

W sprawie wydała nawet opinię Komisja Rządowa Sprawiedliwości, która z powołaniem się na obowiązującą wówczas procedurę karną (§ 32 i 33 Ordynacji Kryminalnej Pruskiej ${ }^{40}$ i $\S 320$ i 321 cz. I Postępowania Kry-

\footnotetext{
${ }^{35}$ Tamże.

${ }^{36}$ Tamże.

${ }^{37}$ M. Senkowska, Kara więzienia..., s. 121.

${ }^{38}$ ZPA, cz. VI, t. II, s. 635.

${ }^{39}$ Tamże, s. 631.
}

${ }^{40} \S 32$ - „Każdy więzień może być nawiedzanym przez duchownego swego wyznania, w przytomności urzędnika sądowego. Jeżeli zaś nie zachodzi żadna obawa, sędzia mocen jest dozwolić duchownemu obcować z więźniem na osobności";

$\S 33$ - „Gdzie tego okoliczności dozwola, będzie więźniom udzielana od czasu do czasu nauka religii przez duchownego"; 
minalnego Austriackiego ${ }^{41}$ ) wyraziła pogląd, iż żądaniu starozakonnych nie można odmówić zasadności ${ }^{42}$.

Ostatecznie Rada Administracyjna w dniu 1/13 maja 1845 r., godząc prawo osadzonych do pomocy religijnej z zasadą bezpieczeństwa i prawidłowego toku postępowania karnego, wydała decyzję określającą zasady udzielania opieki duchowej przez rabinów „rozróżniając więźniów starozakonnych na osadzonych w więzieniach badawczych i więzieniach karnych" ${ }^{\prime 3}$.

I tak zakazano rabinom kontaktu z uwięzionymi w domu badań, wobec których nie zakończono jeszcze śledztwa. Wyjątek zrobiono dla osób dotkniętych ciężką i niebezpieczną chorobą, poświadczoną przez lekarza więziennego: "gdy podług zapewnienia dozoru bóżniczego miasta Warszawy, jest u starozakonnych obowiązkiem słuchania spowiedzi chorych ciężką chorobą złożonych, przeto do takich tylko chorych Rabin do odbycia spowiedzi używanym być może, względem których lekarz więzienny zapewni, że są w niebezpieczeństwie życia" ${ }^{44}$. Jednakże spowiedź mogła odbyć się tylko w obecności nadzorcy, według określonej procedury. Rabin wypisywał na papierze $\mathrm{w}$ języku polskim i poświadczał formułę składającą się z 24 wyrazów, a następnie powtarzał ją głośno i powoli ${ }^{45}$.

Osobom zaś po wyroku zezwolono udzielać opieki duchowej na każde ich żądanie (choć zawsze w obecności nadzorcy), "gdy znoszenie się takowych z osobami postronnymi, a tem samym i Rabinem, nie przedstawia żadnego niebezpieczeństwa pod względem sądowym, przeto dozwolić tymże ilekroć tego żądać będa, uciekanie się do pociech religijnych, bez wymagania ścisłego wykonywania tych ostrożności, jakie co do więźni osadzonych $\mathrm{w}$ domach badań lub będących jeszcze pod śledztwem są zastrzeżone" ${ }^{\prime 46}$. Prawa tego pozbawiono jednak skazanych, którzy wmieszani byli w inne jeszcze sprawy, w których nie ukończono dotąd śledztwa ${ }^{47}$.

${ }^{41} \S 320$ - „Gdyby Lekarz niebezpieczeństwo śmierci aresztowanego uznał; Xiądz właściwie do starania około Dusz przeznaczony, dla duchownego opatrzenia do onegoż przypuszczony być powinien".

$\S 321$ - „W powszechności nikt do Aresztowanego przyjść, ani się z nim rozmawiać może, chyba za wyraźnym pozwoleniem Sądu i to w przytomności takiego onegoż officialisty, któryby rozumiał język, w którym rozmowa czyniona będzie. Równie też Aresztowany nie może wiadomości inaczej komu dać, ani od kogo innego oręż odebrać, iak tylko ustnie i to nawet przez sam Sąd zbrodniowy".

${ }^{42}$ ZPA, cz. VI, t. II, s. 631.

${ }^{43}$ Tamże, s. 637.

${ }^{44}$ Tamże, s. 633.

${ }^{45}$ Tamże.

${ }^{46}$ Tamże, s. 637.

${ }^{47}$ Tamże. 
Przewidywano też, ale tylko w więzieniach karnych, możliwość nauczania religii $\mathrm{w}$ wymiarze 1 godziny $\mathrm{w}$ tygodniu. Jednakże nauka ta mogła odbywać się tylko w języku polskim i w obecności nadzorcy, który pilnował, aby rabin nie „dopuścił się jakichkolwiek zboczeń od celu, w którym jest powołany" 48 .

Jednakże owa posługa religijna opatrzona była pewnymi warunkami. I tak rabin „powinien być znany Zwierzchności z dobrych zasad i nienagannej konduity". Nie mógł on w wykonywaniu tych obowiązków wyręczać się innymi osobami, chyba że zachodziła przyczyna ciężkiej choroby duchownego. $W$ takich przypadkach rabin miał prawo wyznaczyć swego zastępcę, jednak musiał on legitymować się takimi samymi przymiotami ${ }^{49}$.

Dodatkowo Rząd Gubernialny Warszawski polecił nadzorcy więzienia piotrkowskiego, ,aby dozwolonych wizyt Rabinów założył i utrzymywał ciągle kontrolę obejmującą nazwisko Rabina, dzień jego przybycia, przez jak długi czas i w czyiej imiennie ze służby do nadzoru zatrudniał się $e^{\prime 50}$.

Jak wskazuje analiza materiału źródłowego, po 1845 r. msze zarówno w piotrkowskim domu badań, jak i w więzieniu karnym były regularne. Odbywały się one kilka razy do roku z okazji ważniejszych świąt. Zawsze jednak dozór bożniczy zwracał się do Sądu Policji Poprawczej Wydziału Piotrkowskiego o wyrażenie zgody na gromadzenie się wszystkich Żydów w jednej izbie w celu wspólnego odbywania modłów. Władza sądownicza zasadniczo przychylała się do tych wniosków. Jednakże zdarzało się, że czyniła pewne wyłączenia. Tak np. w 1846 r. Sąd Policji Poprawczej nie zezwolił na wspólne nabożeństwa z okazji Świąt Wielkanocnych 13 aresztantom, „z którymi śledztwo dotąd nie jest ukończone, a przez zmowę na uszczerbek mogłoby być nastawione" ${ }^{\prime \prime 1}$. W innym piśmie, z 1856 r., sąd wyrażając zgodę "zgromadzać się dwa razy na dzień na modlitwę do jednej kaźni wobec duchownych ich wyznania", jednocześnie pozbawił tego uprawnienia dwóch aresztantów, którzy ,jjako do jednej sprawy wchodzący odosobnieni od siebie być winni" ${ }^{52}$.

Nie wiemy, czy wspomniana opieka duchowa przybierała też inny charakter, np. nauk religijnych. Choć można przypuszczać, że gdyby takie działania rabinów były faktem, to jakiś ślad w materiale archiwalnym by pozostał.

Pewien problem stanowiła kwestia wyżywienia Żydów w trakcie świąt. Instrukcja więzienna z 1823 r. nie regulowała szczegółowo tego za-

\footnotetext{
${ }^{48}$ Tamże, s. 635.

${ }^{49}$ Tamże, s. 633.

${ }^{50}$ APŁ, Więzienie Piotrkowskie..., sygn. 15.

${ }^{51}$ Tamże.

${ }^{52}$ Tamże.
} 
gadnienia, stanowiąc tylko w art. 71, iż „nie można więźnia wyznania Mojżeszowego przymuszać do jedzenia potraw ze słoniną i na ich żądanie masłem zamiast słoniną potrawy okraszać należy" ${ }^{\prime \prime 3}$. Jak podaje M. Kaczyńska praktyką stało się, że więźniowie starozakonni w trakcie ważniejszych świąt dostawali od gmin wyznaniowych dodatkowe rytualne pożywienie ${ }^{54}$. $\mathrm{Z}$ tą praktyką władze starały się walczyć. I tak w 1845 r. Rada Administracyjna nie uwzględniła żądania, aby w każdym szpitalu i więzieniu był jeden starozakonny do gotowania pożywienia współwyznawcom, nakazując w tym względzie stosowanie przepisów instrukcji z $1823 \mathrm{r} .{ }^{55} \mathrm{~W}$ roku 1851, postanowieniem namiestnika, wydanym na wniosek komisji Rządowej Spraw Wewnętrznych i Duchownych zakazano dostarczania więźniom żydowskim jakichkolwiek dodatkowych pokarmów. Nakaz ten nie był jednak ściśle przestrzegany, o czym świadczy pismo Rządu Gubernialnego Warszawskiego z 15/27 marca 1851 r., w którym czytamy: „gdy niektórzy z nadzorców więzień pociągnięci do wyjaśnienia zboczeń $\mathrm{w}$ tym względzie powoływali się na wyrzeczenia Sądów zarządzające takowe ulepszenia dla Żydów żywności, komisja Rządowa Spraw Wewnętrznych i Duchownych wezwała Komisję Sprawiedliwości, aby powyższa decyzję Jego Książęcej Mości oznajmiła także sądom" ${ }^{\prime 56}$. Ostatecznie jednak na skutek odwołania dozoru bożniczego miasta Warszawy, który podnosił, iż „dostarczanie Starozakonnym w czasie Świąt Wielkanocnych żywności stosownie do przepisów religijnych przyrządzonych, należy do kardynalnych zasad Wyznania Mojżeszowego", złagodzono te zasady. I tak Komisja Rządowa Spraw Wewnętrznych i Duchownych "godząc przepisy kardynalne Religii Mojżeszowej z warunkiem nie powiększania lub nie polepszania żywności dla więźniów tegoż wyznania" zezwoliła gminom żydowskim na dostarczanie świątecznej żywności pod warunkiem, że będzie zgodna z ustaloną taryfą więzienną $a^{57}$.

Kolejna instrukcja więzienna z 1859 r. w większości utrzymywała zasady udzielania pomocy religijnej starozakonnym ustalone przez Radę Administracyjną w $1845 \mathrm{r}$. Pewne zaś nowe regulacje, jak wynika z zachowanych archiwaliów, stanowiły w zasadzie usankcjonowanie przyjętej wcześniej praktyki ${ }^{58}$. I tak w art. 88 instrukcji zezwolono Żydom na wspólne odbywanie modłów z okazji ważniejszych świąt, a każde wejście rabina do

${ }^{53}$ ZPA, cz. VI, t. I, s. 367.

${ }^{54}$ M. Kaczyńska, Ludzie ukarani. Więzienia i system kar w Królestwie Polskim 1815-1914, Warszawa 1989, s. 394.

${ }^{55}$ ZPA, cz. VI, t. II, s. 631-137.

${ }^{56}$ APŁ, Więzienie Piotrkowskie..., sygn. 15.

${ }^{57}$ Tamże.

${ }^{58}$ Tamże. 
więzienia mogło nastąpić tylko za zgodą sądu (art. 90). Nowym istotnym przepisem była jedynie możliwość wyrażenia przez sąd zgody na uczestniczenie osób przebywających w domu badań pod śledztwem we wspólnych nabożeństwach, o ile nie zagrażało to bezpieczeństwu więziennemu ${ }^{59}$.

Po wydaniu nowej instrukcji aktywność rabinów w piotrkowskim domu badań, jak i więzieniu karnym, utrzymała się na podobnym poziomie. Nadal posługa religijna opierała się na odprawianiu kilka razy do roku świątecznych nabożeństw. Można jednak zauważyć, że Sąd Policji Poprawczej Wydziału Piotrkowskiego rzadziej stosował wobec aresztantów zakaz uczestniczenia we wspólnych mszach aniżeli w okresach wcześniejszych ${ }^{60}$.

\section{Inne wyznania chrześcijańskie}

Sytuacja więźniów innych wyznań chrześcijańskich, podobnie jak Żydów, przez długi czas nie była uregulowana odrębnymi przepisami. Jednak wydaje się, że nastawienie władz Królestwa Polskiego do nich było pozytywne. W więzieniach odnotowano obecność osób religii ewangelickiej. W 1843 r. Komisja Rządowa Spraw Wewnętrznych i Duchownych wezwała Konsystorza tego wyznania, aby dostarczył książki do obywania modłów - po jednej dla każdego więzienia ${ }^{61}$. Instrukcja więzienna z 1859 r. regulowała bardzo ogólnikowo sytuację osób innych wyznań chrześcijańskich, stanowiąc w art. 87, że „pomoc duchowna więźniom innych wyznań Chrześcijańskich udzielaną będzie w razie żądania tego przez nich, o czem Nadzorca właściwego duchownego uprzedza. Za posługę religijną pobierać będą duchowni wynagrodzenie tam tylko, gdzie to jest etatem oznaczone i w ilości nieprzenoszącej tego oznaczenia" ${ }^{\prime \prime 2}$.

Zachowany materiał źródłowy daje podstawy do przypuszczenia, że do lat czterdziestych więźniowie poza osobami wiary rzymskokatolickiej pozbawieni byli opieki duchowej. Dopiero w 1845 r. pastor Parafii Ewangelickiej Piotrkowskiej zwrócił się do nadzorcy więzienia piotrkowskiego, iż „ponieważ wszystkim wyznawcom ewangelickim bez różnicy więźnia być winna pomoc religijna, mam honor przeto wezwać Nadzorcę, aby raczył mi donieść ile możności w jak najkrótszym czasie, czy są w więzieniu tutejszym aresztanci wyznania ewangelickiego, abym tymże mógł słowa pociechy re-

\footnotetext{
${ }^{59}$ ZPA, cz. VI, t. II, s. 79-81.

${ }^{60} \mathrm{APŁ}$, Więzienie Piotrkowskie..., sygn. 15.

${ }^{61} \mathrm{ZPA}, \mathrm{cz} . \mathrm{VI}, \mathrm{t}$. IV, s. 115.

${ }^{62} \mathrm{ZPA}, \mathrm{cz}$. VI, t. II, s. 79.
} 
ligijnej jako ma już miejsce z wyznawcami Rzymsko-Katolickimi". W odpowiedzi nadzorca podał, że „w domu badań znajduje się 10 osób wyznania ewangelickiego, którym nauk religijnych żadna nie zachodzi przeszkoda" ${ }^{63}$.

Innym wyznaniem była religia augsbursko-ewangelicka. I tak z pisma nadzorcy domu badań z 15/27 marca 1858 r. kierowanego do księdza proboszcza dowiadujemy się, że w areszcie znajduje się dziewięciu wyznawców tego obrządku. W dokumencie nadzorca pyta duchownego, kiedy może on przyjąć od więźniów spowiedź Wielkanocną. Co ciekawe czynność ta miała odbyć się nie w kaplicy więziennej, ale w kościele ${ }^{64}$. Jednak w kolejnych latach duchowny przybywał już do więzienia, by udzielić posługi religijnej aresztantom. Niestety nie mamy informacji o powodach, dla których w 1858 r. spowiedź miała odbyć się poza murami zakładu karnego.

Odnotowujemy nadto przypadek przebywania w piotrkowskim więzieniu aresztanta prawosławnego. I tak w piśmie z 24 marca/5 kwietnia 1860 r. proboszcza parafii prawosławnej czytamy: „mam honor zawiadomić, iż znajdujący się pod aresztem w Domu Badań tutejszym Włodzimierz Łojewski Religii Prawosławnej może rozpocząć rekolekcje do spowiedzi od dnia dzisiejszego do przyszłej soboty i dlatego więc niech przybędzie do cerkwi prawosławnej dziś o godzinie $10 \mathrm{z}$ rana". Z dokumentu nie wynika, dlaczego duchowny nakazał dostarczenie aresztanta do cerkwi, jednakże można przypuszczać, iż w tym przypadku mogły zadecydować względy ekonomiczne, gdyż chodziło tylko o jedną osobę.

Na podstawie dostępnych źródeł brak jest możliwości odtworzenia szczegółowych zasad udzielania posługi religijnej wyznawcom innych religii chrześcijańskich. Zachowało się jedynie kilka dokumentów, które co najwyżej dają prawo do stwierdzenia, że takie osoby bywały osadzone w więzieniu piotrkowskim, choć raczej były to przypadki marginalne. Więźniowie ci mieli kontakt $\mathrm{z}$ duchownymi swojego wyznania, ale zakres tej posługi był niewielki i odbywał się tylko przy okazji najważniejszych świąt.

\section{Zakończenie}

Na kanwie XIX-wiecznych nowatorskich poglądów na cele i zasady wykonywania kary pozbawienia wolności, w myśl których jednym z podstawowych zadań więziennictwa była resocjalizacja skazanych, władze Królestwa Polskiego podjęły pewne realne działania.

\footnotetext{
${ }^{63}$ APŁ, Więzienie Piotrkowskie..., sygn. 15.

${ }^{64}$ Tamże.
} 
I tak już instrukcja więzienna z 1823 r. zawiera pierwsze regulacje przewidujące obecność kapłanów w jednostkach penitencjarnych. Były one jednak mało precyzyjne, a udział duchownych w życiu społeczności więziennej miał być raczej skromny. Komisja Spraw Wewnętrznych i Duchownych nie widziała chyba księży w roli przewodników duchowych skazanych, a ograniczała ich rolę tylko do odprawiania okolicznościowych mszy i udzielania sakramentu chorym.

Istotna zmiana nastąpiła w 1838 r., gdy władze Królestwa Polskiego (inspirowane szeroką działalnością w tym zakresie Fryderyka Skarbka) zdecydowały się istotnie szerzej określić zadania kleru. Każde więzienie miało mieć stałego kapelana, który powinien stanowić istotne ogniwo na drodze odnowy moralnej przestępców.

Ostatnie omawiane przepisy, pochodzące z 1859 r., stanowiły pewien krok wstecz. Ponownie rola duchownych sprowadzała się zasadniczo do odprawiania świątecznych nabożeństw, nieco szersza posługa duchowa miała odbywać się tylko w większych więzieniach karnych. Co istotne, zasadniczo ograniczono nauki religijne, które odtąd mieli pobierać tylko więźniowie małoletni.

W latach czterdziestych XIX w., w wyniku starań gmin żydowskich, uregulowano zasady udzielania posługi religijnej osobom wyznania mojżeszowego. W tym względzie Rada Administracyjna wykazała dużą nieufność w stosunku do rabinów, podejrzewając ich o zamiar bezprawnych działań. Ostatecznie pozwolono na korzystanie z opieki duchowej Żydom, wobec których zapadł już prawomocny wyrok. Instrukcja z $1859 \mathrm{r}$. utrzymywała w większości dotychczasowe zasady. Co istotne jednak, przyznano starozakonnym "będącym jeszcze pod śledztwem” prawo uczestniczenia we wspólnych nabożeństwach, o ile nie zagrażało to prawidłowemu biegowi postępowania.

W 1845 r. pojawiają się także pierwsze regulacje dotyczące odbywania praktyk religijnych przez ewangelików. Instrukcja z 1859 r. odnosiła się ogólnie do innych wyznań chrześcijańskich, przyznając wiernym zasadniczo prawo do opieki religijnej. Nie było jednak wiadomo, jaki miał być jej zakres i forma.

Analiza materiału archiwalnego wskazuje, że najwięcej w więzieniu piotrkowskim było wyznawców religii rzymskokatolickiej i mojżeszowej. Przy czym zupełnie inne było nastawienie duchownych tych obrządków do posługi religijnej niesionej więźniom. Duchowni rzymskokatoliccy, którym zostały stworzone znaczne możliwości niesienia pomocy duchowej osadzonym, nie byli tą forma duszpasterstwa zbytnio zainteresowani. Działalność ich opierała się zasadniczo na odprawianiu raz w roku, z okazji Wielkanocy, nabożeństwa, wtedy też skazańcy mogli przystąpić 
do spowiedzi i przyjąć komunię świętą. Sytuacja ta nie zmieniła się także po 1838 r., gdy Komisja Rządowa Spraw Wewnętrznych i Duchownych starała się wykorzystać rolę księży, jako przewodników duchowych przestępców.

\section{Bibliografia}

\section{Źródła}

Archiwum Państwowe w Łodzi, zespół nr 73, Więzienie Piotrkowskie 1809-1914.

\section{Akty normatywne}

Zbiór Przepisów Administracyjnych Królestwa Polskiego, Wydział Spraw Wewnętrznych, cz. VI, O aresztach i więzieniach, t. I, II, IV, 1868.

\section{Opracowania}

Bardach J. (red.), Historia Państwa i Prawa Polski, t. III, Warszawa 1981.

Czacki T., O litewskich i polskich prawach, t. II, Warszawa 1801.

Czerwiec M., Więzienioznawstwo. Zarys rozwoju więziennictwa, Warszawa 1958.

Kaczyńska M., Ludzie ukarani. Więzienia i system kar w Królestwie Polskim 18151914, Warszawa 1989.

Niemcewicz J. U., O więzieniach publicznych, czyli Domach Pokuty rzecz krótka, Warszawa 1818.

Nikołajew J., Duszpasterstwo więzienne. Tradycje. Teraźniejszość. Perspektywy, Lublin 2009.

Osoba A., Z dziejów polskiej dziewiętnastowiecznej myśli penitencjarnej, „Przegląd Więziennictwa Polskiego" 2001, nr 32-33.

Pawlikowski J., O prawach kryminalnych, Warszawa 1918.

Potocki K., Uwagi do projektu ogólnego i szczególnego ulepszenia administracji i stanu więzień publicznych w Królestwie Polskim, Warszawa 1819.

Rappaport E. S., Polityka kryminalna w zarysie, Łódź 1948.

Senkowska M., Kara więzienia w Królestwie Polskim w pierwszej połowie XIX wieku, Wrocław-Warszawa-Kraków 1961.

Skarbek F., O poprawie moralney winowayców w więzieniach, Warszawa 1822.

Śliwowski J., Narodziny prawa penitencjarnego, Warszawa 1934. 